\title{
The Perception of Market and Economic Risks by Owners and Managers of Enterprises in the V4 Countries
}

\author{
- Maria Hudakova, Marie Gabrysova, Zora Petrakova, Katarina Buganova, \\ Vladimir Krajcik
}

\begin{abstract}
The aim of the paper is to assess the impact of the length of entrepreneurship on the perception of the most important business risks in Slovakia and the Visegrad Group of Countries (V4 countries). The empirical research was conducted in 2019-2020. It was focused on assessing the state of enterprise risk management (ERM) application. The research file contained 422 online questionnaires completed by owners and managers of enterprises (OMEs). The results of this case study were compared with the results of similar studies performed in the V4 countries in 2017-2018. In total, 1,781 OMEs participated in the surveys mentioned. The following statistical methods were used to assess the data: ANOVA, Bartlett's test, Agostini test, good fit test, and Grubbs test. The overall results of the empirical research highlight the significance and importance of the assessment of business risks in the V4 countries. The results in Slovakia in 2019-2020 and the research results in the V4 countries in 2017-2018 show that OMEs still consider market and economic risks to be most important in their business. Market and economic risks are related to sources that exert the most negative influence on enterprise success. The results are valuable for entrepreneurs, enterprise managers and institutions that provide comprehensive entrepreneurship support in the V4 countries. The overall results are significant at the regional, national, and international levels of the V4 countries and have the ability to strengthen the competitiveness of entrepreneurs within the EU common market.
\end{abstract}

Keywords: market risk, economic risk, risk, management, V4 countries, enterprises

JEL Classification: M21, G32, L52, L26

Received: June, 2021

1st Revision: October, 2021

Accepted: October, 2021

\section{INTRODUCTION}

The current situation in the world caused by the COVID-19 pandemic has confirmed the need to be prepared for adverse situations in the business environment (Achim et al., 2021; Kljucnikov et al., 2021). Changes in the business environment, slowdowns in economic development, declines 
in orders, production changes, and other changes must currently be accepted by enterprises. Under these conditions, owners and managers must make important decisions to ensure the prosperity, financial stability, and very existence of their businesses. According to Reçica et al. (2019) and Gavurova et al. (2017), crisis situations in the business environment can be eliminated through the effective application of ERM. In addition, some studies document the positive effects of risk management on increasing an enterprise's value, ensuring its competitiveness, and providing opportunities for achieving profits (Dvorský et al., 2021; Belas et al., 2020). According to Schmidt (2020), the assessment and treatment of the risks affect the quality of the information provided, decision-making affected by the risk, and prevention within the framework of ensuring the smooth running of a business. Nevertheless, many enterprises rarely conduct activities related to the risk management process or apply it incorrectly. According to Kulathunga et al. (2020), the limited resources (financial and human) that enterprises have at their disposal influence this and the risk management process itself. Some owners and managers have an incorrect approach to risks. In most cases, the risks arising from the internal and especially the external environment are underestimated (Adapa \& Fisher, 2020; Smith, 2020). Gilmore et al. (2004) claim that some enterprises do not have early warning systems and do not identify, analyse, and evaluate risks. Their system of preventive measures usually aims to ensure that managers respond to the negative consequences of problems only (Demirbas et al., 2011). Managers do not have sufficient knowledge of risk management methods and tools and the ability to assess the risks of key business processes (Hernández-Madrigal et al., 2020).

According to studies (Belas et al., 2018; Kiseleva et al., 2018; Oláh et al., 2019), owners and managers pay more attention to external risks, e.g. market and economic risks; and internal risks, e.g. operational and personnel risks. Of course, it is important to monitor the development of the competitive environment and assess customer losses, market stagnation, supplier unreliability, the growth of the process of all types of energy, the insufficient availability of financial resources, and increased interest rates. (Lechner \& Gatzert, 2018). Based on the obtained and processed studies, the authors decided to assess the market and economic risks that are most important for businesses to ensure profit, success, and competitiveness, especially for enterprises in Eastern Europe. The V4 countries create a certain concept of association and appropriate coordination. They work together to find positions on how to solve key problems that help increase the competitiveness, economic development, and resilience of companies to global influences.

The paper aims to evaluate the importance of determinants of the market and economic risk level perception by enterprise owners and managers and to assess the impact of the market and economic risks of enterprises in Slovakia and the V4 countries to evaluate the market and economic risks in terms of the length of entrepreneurship (LE) to increase enterprise competitiveness within the V4 countries. One aim of the paper is to increase the promotion of risk management and overall prevention in enterprises at the international level, which is directly linked to increasing the competitiveness of enterprises and managing corporate crises in the current business environment affected by the COVID-19 pandemic.

The originality of this paper is that the paper presents unique results from empirical research in Slovakia (SR) in 2019-2020 and the results of similar studies performed in the V4 countries (SR, the Czech Republic (CR), Poland (PL), and Hungary (HU)) in 2017-2018. The paper identifies 
the key risks in the V4 countries, assesses the significant determinants of the perception of the level of market and economic risks by owners and managers in terms of LE, and considers the market development during 2017-2020 for enterprises in SR. The originality of the paper also includes the duration of the research (four years), which highlights the seriousness of the research conducted with substantiated evidence in the field of business risks from a long-term perspective and real results usable in practice.

The main structure of this paper consists of the following parts: i. the literature review reviews market and economic risks; ii. the methodology describes the methods, research questions, and hypotheses; the results address the acceptance/rejection of the established hypotheses and assess the market and economic risks of enterprises, and the discussion and conclusion summarize the results that are interesting for OMEs in the V4 countries.

\section{THEORETICAL BACKGROUND}

In a number of scientific studies and standards worldwide, the term risk is defined in different ways. The definition depends on the field of activity, the purpose of the definition and its intended use (Hvolkova et al., 2019). There are different views and definitions of risk from different authors. For example, according to the STN ISO 31 000: 2011 standard, the risk is defined as the effect of uncertainty on objectives. An effect is a deviation from the expected. An effect can be positive, negative, or both (De Oliveira et al., 2017). Objectives can have different aspects and categories (such as financial, health, safety, and environmental) and can be applied at different levels (such as the strategic level, within an entire organization, or within a project, product, or process). Holla et al. (2010) understand risk as the probability that an event will occur with a certain probability that differs from the expected state or development. Risk should not be reduced to likelihood itself as it does not include both the likelihood itself and the quantitative extent of the event. It is important to indicate the level of risk that needs to be accepted (Wu et al., 2015). Every enterprise must respect a certain risk that arises in the performance of its activities (Varadarajan, 2020). Klinke (2020) understands risk as a certain relationship between the functions and objectives of a given entity and between those factors of the external or internal environment that are capable of endangering those functions and objectives in a given situation.

Business risks introduce an element of uncertainty into entrepreneurial activity, which can influence the course and development of a certain economic activity (Lončarski \& Marinč, 2020) and even endanger the expected effect and results (Khan et al., 2019). This means that from the point of view of business decision-making, there are two components to risk: uncertainty (understood neutrally in relation to the subject) and the negative impact of uncertainty on the subject (Egbunike \& Okerekeoti, 2018). According to Hnilica et al. (2019), business risk is a danger (uncertainty) that the achieved results of business activity will deviate from the expected results. Deviations may be desirable (for higher profits) or undesirable (for loss) and of different magnitudes (small-scale deviations that are results are close to expected results and large-scale deviations that are significant business successes in case of desired deviations or significant financial difficulties to bankruptcy in case of undesirable deviations). Risk can be expressed in several ways (standard deviation, coefficient of variation, frequency, distribution functions, the 
relative deviation between actual and expected loss, etc.) According to Fraser \& Simkins (2016), risk can be reduced by taking preventive measures and performance measures and by being aware of the risk itself. The approach to risk and the degree of its acceptance depends on the individual preferences and values of the person responsible for risk management in the given entity. An individual's approach to risk represents his business strategy (Racitot \& Théoret, 2018; Chavarín, 2020).

Businesses operate in an environment that is influenced by a number of macroeconomic factors and trends that affect them, determine the possibilities for their development, and, at the same time, represent a potential risk source. The terms market and economic risks are defined in the scientific literature as follows.

Market risks are associated with the application of products and services in domestic and foreign markets. They are closely linked to the competitive activity, to the behaviour of customers, and to the manner and speed of saturation of the market. They mainly take the form of selling or pricing risks. According to Avilova et al. (2017), market risks are mainly influenced by marketing factors (e.g. market research and advertising), price (e.g. selling price strategy and global prices of products, materials, and raw materials), and position (e.g. the technical and technological attractiveness of the product). According to Virglerova et al. (2020), market risk also includes differences in mentalities, language barriers, differences in legal systems, long distances between the parties, etc. According to Green (2016), market risk is systematic and results from the character of the external company environment. It concerns all companies differently because it is connected with the uncertainty resulting from economic development. Dean et al. (2019) characterise market risks from the point of view of creating value as the risks of new opportunities on the market (new technologies, changing requirements of customers, etc.). Some authors understand market risks more as marketing or entrepreneurial risks (Dvorský et al., 2019). According to Adkins et al. (2013), the market risk-related sources that exert the most negative influence on enterprise success are increased competition, limited market size, low demand, inefficient marketing, poor understanding of competitors, poor understanding of location and markets, and the inability to identify the target market.

Economic risks form a wide range of risks arising mainly from the changes in the prices of individual cost items, e.g. rising prices of raw materials, materials, energy, and services. There are risks arising from the cost structure, i.e. the ratio between fixed and variable costs (Bogodistov \& Wohlgemuth, 2017). According to Brunner-Kirchmair \& Wiener (2019), economic risks concentrate on macroeconomic circumstances that may result in a significant loss for a business. These conditions include inflation, exchange rate fluctuations, political instability, the introduction of economic sanctions, new government regulations, and other decisions that may adversely affect profits. According to Mura \& Kajzar (2019) and Beasley \& Frigo (2011), economic risks also include risks associated with foreign trade activities and doing business abroad. Economic risk refers to the likelihood that macroeconomic conditions (the conditions in the entire economy) may affect an investment or a company's prospects domestically or abroad (Oláh et al., 2019). Economic risk is basically the aggregate effect of all sub risks expressed in monetary units (Ayyagari et al., 2007). Economic risks are often the most difficult ones to foresee. Without an economic risk management strategy, enterprises put their business, its current 
profitability, and its potential growth at risk. For the most effective economic risk management strategy, enterprises must first understand the variety of economic threats to their business (Green, 2016). The impact of risk management in relation to the length of business also has a significant impact on the competitiveness of SMEs. According to Dvorský et al. (2021), a lack of experience, a lack of capital, risk aversion, a lack of technical knowledge, and tax aspects are the most critical barriers to business. Companies with a longer duration of existence prefer more foreign capital to finance their activities. The reasons are related to financial risks and access to foreign sources of financing (Belas et al., 2018). The age of an enterprise's operations in a market also impact the attitude towards risk. Enterprises that have been operating in a market for over 10 years do not make risky investments as often as younger enterprises. Once again, this may be associated with the experience of entrepreneurs based on the age and the duration of operating in a market (Lazányi et al., 2017).

\section{RESEARCH OBJECTIVE, METHODOLOGY AND DATA}

The aim of the paper is to define and quantify the most significant business risks and show the differences in these risks according to the length of business.

In 2017-2018, empirical research aimed to identify the key business risks and the current state of applying ERM in other V4 countries (CR, PL, and HU). The questions were asked through online questionnaires in the national languages of the entrepreneurs. One part of the questionnaire was questioning about ERM. Next, information was obtained by a structured interview with the managers of selected enterprises. The purpose of the research and this specific selection was to obtain data on the identified key risks perceived by owners and managers of the enterprises in the V4 countries.

In 2019-2020, 422 owners and managers running a business in SR participated in the research. The structure of the sample was as follows: i. by the time period of operating a business: 60 enterprises had operated for less than 5 years, 110 enterprises had operated from 6 to 10 years, and 252 enterprises had operated for more than 10 years; ii. the highest education level of the entrepreneur attained: 219 respondents did not possess a university education and 203 respondents possessed a university education; iii. gender of the entrepreneur: 277 men and 145 women; and business sector: 88 in trade, 75 in industry, 66 in the building industry, 42 in transport and information, 43 in other services, 27 in agriculture, 24 in accommodations and boarding, 15 in trade services and 42 in the remaining services.

In 2017-2018, 1,781 owners and managers running a business in the V4 countries (CR/PL/HU/ SR) participated in the research. The structure of the sample was as follows: i. nationality of OMEs: 408/498/388/487; ii. by the period of operating a business: 84/101/92/111 enterprises for less than 5 years, 80/161/113/126 enterprises from 6 to 10 years, and 244/236/183/250 enterprises for more than 10 years; iii. the highest education level of the entrepreneur attained: $272 / 281 / 279 / 315$ with no university education and 136/217/109/172 with university education; iv. gender of entrepreneur: 290/311/232/325 men and 118/187/156/162 women; and v. sector of business: $93 / 158 / 76 / 119$ in trade, $91 / 74 / 41 / 79$ in industry, 63/34/20/59 in the building industry, 20/57/24/31 in transport and information, 63/29/98/105 in other services, 15/30/62/5 
in agriculture, 25/31/41/43 in accommodations and boarding, 25/85/17/32 in trade services and $13 / 0 / 9 / 14$ in the remaining services.

The results were processed according to the following steps: i. Identify the key risks perceived by OMEs in Slovakia based on the survey results in 2019-2020, ii. Assess the significant determinants of the market and economic risks perceived by OMEs from the perspective of their LE in Slovakia based on the survey results in 2019-2020, iii. Identify the key risks perceived by OMEs in the V4 countries based on the survey results in 2017-2018, iv. Assess the significant determinants of the market and economic risks perceived by OMEs from the perspective of their LE in the V4 countries based on the survey results in 2017-2018, and v. Compare the processed results from the studies in 2017-2018 and 2019-2020.

The created questionnaire consisted of three main parts: Part 1 - basic elements of risk management, Part 2 - ERM application, and Part 3 - identifying the risks and sources of risk of enterprises. The addressed OMEs in SR identified a maximum of three risks from the selected seven risks that they consider to be the key risks in their businesses. Additionally, they evaluated the current state of application of ERM in terms of problems, the level of ability and skills of managers to apply ERM, the level of application methods and techniques of ERM, etc. The composition of the questions was based on the authors' own experience within the framework of scientific and national projects, an analysis of the current state of the solved issues in the world, and work experience. The questionnaire consisted of 24 questions. A modified Likert scale (11 points - the intensity of risk source from $0 \%$ to $100 \%$ ) was used to evaluate the questions.

Based on the research questions mentioned, the following null hypotheses were established $(\mathrm{H})$ :

H1: There are no statistically significant differences in the level of perception of the market risks (H1A) or economic risks (H1B) by OMEs in SR (H1A_SR and H1B_SR, respectively) and in the V4 countries (H1A_V4 and H1B_V4, respectively) in terms of LE.

$\mathrm{H} 2$ : There are no statistically significant differences between the perception of the market and economic risks by owners and managers in SR and the V4 countries based on LE.

The statistical hypotheses (H1 and H2) were assessed using the following tests: one-way ANOVA - analysis of variance, Bartlett's test of sphericity, D'Agostino's test, and the test of the goodness of fit for verification of normality. The Grubbs test was used to assess the outliers and selected indicators of the basic descriptive characteristics (BDCHSs). The level of significance $(\alpha)$ was 0.05. Using the test calculations, two basic assumptions had to be met: the p value of the tested criterion of the homoscedasticity test (the identity of variances) and the normality test to verify the intensities of risks must be higher than $\alpha$.

\section{RESULTS}

\subsection{Identifying the key risks perceived by OMEs in SR - the 2019-2020 survey}

Based on the main aim of the survey conducted in 2019-2020, we can summarize the main results. In total, 422 OMEs in SR identified three key risks possibly affecting their business activities. The identified risks are as follows (percentage of identified key risks perceived by OMEs in SR): market risk $-26.01 \%$, economic risk $-17.54 \%$, financial risk $-16.82 \%$, personnel 
risk $-14.61 \%$, operational risk $-9.29 \%$, security risk $-6.36 \%$, legal risk $-4.26 \%$ and other risks $-5.11 \%$.

The owners and managers of the enterprises identified market risks as the most serious risks for the enterprises in SR in 2019-2020. The research results show that enterprises are most vulnerable to the market environment. This can also be proven by other results that point to the most significant intensity of the market risk sources for enterprises as follows: the loss of customers, strong business competition, market stagnation, and unreliable suppliers. Economic risks also affect the business of enterprises. These risks were identified as the second most serious risks for the enterprises within the research framework in SR in 2019-2020. The largest sources of economic risks were as follows: increased tax and insurance burdens, increased employee wages, increased prices of all types of energy, insufficient availability of financial resources, and increased interest rates.

\subsection{Assessment of the market and economic risks by OMEs from the perspective of their LE in SR - the 2019-2020 survey}

It was necessary to use descriptive statistics to better analyse the assessed data and to verify the established hypotheses (Table 1).

Tab. 1 - BDCHSs of the market and economic risks perceived by owners and managers according to LE. Source: own research

\begin{tabular}{|l|l|l|l|l|l|}
\hline \multirow{2}{*}{ Risks } & \multirow{2}{*}{ BDCHS } & \multicolumn{3}{|l|}{ Interval of entrepreneurship } \\
\cline { 3 - 6 } & $\begin{array}{l}\text { Less than five } \\
\text { years }\end{array}$ & $\begin{array}{l}\text { From five to } \\
\text { ten years }\end{array}$ & $\begin{array}{l}\text { From ten to } \\
\text { twenty years }\end{array}$ & $\begin{array}{l}\text { More than } \\
\text { twenty years }\end{array}$ \\
\hline \multirow{5}{*}{ MRs/ERs } & $\mathrm{N}$ & 60 & 110 & 122 & 130 \\
\cline { 2 - 6 } & $\mu$ & $0.287 / 0.214$ & $0.277 / 0.241$ & $0.287 / 0.178$ & $0.297 / 0.165$ \\
\cline { 2 - 6 } & median & $0.3 / 0.2$ & $0.3 / 0.3$ & $0.3 / 0.2$ & $0.3 / 0.1$ \\
\cline { 2 - 6 } & $\sigma$ & $0.263 / 0.168$ & $0.234 / 0.205$ & $0.237 / 0.186$ & $0.232 / 0.189$ \\
\cline { 2 - 6 } & skewness & $0.9 / 0.18$ & $0.75 / 0.68$ & $0.19 / 0.47$ & $0.37 / 1.23$ \\
\cline { 2 - 6 } & kurtosis & $0.79 /-0.72$ & $0.80 / 0.76$ & $-0.76 /-1.17$ & $-0.15 / 1.93$ \\
\hline
\end{tabular}

Note: MR - Market risks; ER - Economic risks; $\mathrm{N}$ - number of enterprises, $\mu$ - the average intensity of risk to the enterprise, $\sigma$ - standard deviation of risk intensity to the enterprise.

The results of the research show that the most important risks are market and economic risks, which are most often perceived by enterprises in SR based on LE. Based on the Grubbs test of outliers, the outliers were not identified. Bartlett's test (MR: $\mathrm{p}$ value $=0.107$; ER: $\mathrm{p}$ value $=0.069)$ and Levin's test of sphericity $(\mathrm{MR}: \mathrm{p}$ value $=0.319 ; \mathrm{ER}: \mathrm{p}$ value $=0.306)$ confirmed the assumption of sphericity. The D'Agostino test of enterprises running a business for less than 5 years achieved certain values (MR: $p$ value $=0.050$; ER: $p$ value $=0.100)$. The test of the goodness of fit for enterprises running a business from 5 to 10 years (MR: $\mathrm{p}$ value $=0.069$; ER: $\mathrm{p}$ value $=0.079)$, from 10 to 20 years $(\mathrm{MR}: \mathrm{p}$ value $=0.131 ; \mathrm{ER}: \mathrm{p}$ value $=0.0 .099)$ and for more than 20 years (MR: $\mathrm{p}$ value $=0.089 ; \mathrm{ER}$ : $\mathrm{p}$ value $=0.063)$ can be considered to fulfil the presumption of data normality. 
Tab. 2 - Analysis of the intensity variance of the enterprise market and economic risks in SR. Source: own research

\begin{tabular}{|l|l|l|l|l|}
\hline \multirow{2}{*}{ LE } & \multicolumn{2}{|l|}{ Market risks } & \multicolumn{2}{l|}{ Economic risks } \\
\cline { 2 - 5 } & N & $\begin{array}{l}\text { The average per } \\
\text { group }\end{array}$ & N & $\begin{array}{l}\text { The average per } \\
\text { group }\end{array}$ \\
\hline$>$ 5 years & 60 & 50.69 & 60 & 46.29 \\
\hline From 5 to 10 years & 110 & 66.98 & 110 & 55.23 \\
\hline From 10 to 20 years & 122 & 49.66 & 122 & 61.91 \\
\hline$<20$ years & 130 & 63.22 & 130 & 68.75 \\
\hline F-test (P-value) & 0.040 & & 0.012 & \\
\hline
\end{tabular}

Note: $\mathrm{N}$ - Number of enterprises.

The test of the market and economic risks by OMEs in SR was conducted based on the one-way ANOVA (MR: p value $=0.040 ;$ ER: $\mathrm{p}$ value $=0.012 ;$ Table 2 ). There is a statistically significant difference in the perception of market risks by OMEs in SR based on LE. We can reject the established hypotheses H1A_SR and H1B_SR, i.e., OMEs in SR perceive different market risks and economic risks according to LE. They perceive certain risks at the beginning of their business, which changes during the length of running a business.

\subsection{Identifying the key risks perceived by OMEs in the V4 countries - the 2017-2018 survey}

From the research performed in 2017-2018, we can summarize the following results. In cooperation with coresearchers from Poland, the Czech Republic and Hungary, an empirical survey was conducted in the V4 countries, including SR. In total, 1,781 OMEs participated in this survey (Fig. 2). The addressed OMEs in the V4 countries (SR/CR/PL/HU) identified the following key risks for their business: market risks - 26\%/24\%/20\%/19\%, financial risks $-21 \% / 19 \% / 16 \% / 16 \%$, economic risks - 19\%/16\%/14\%/13\%, personnel risks - 11\%/19\%/15\%/13\%, operational risks $-9 \% / 10 \% / 12 \% / 14 \%$, legal risks $-7 \% / 6 \% / 11 \% / 9 \%$, security risks $-6 \% / 5 \% / 12 \% 11 \%$ and other risks $1 \%$ in SR.

The summarized results of the identified key risks perceived by OMEs from the V4 countries are as follows $(1,781$ companies; in $\%)$ : market risk - 22.0\%, financial risk - $18.0 \%$, economic risk $16.0 \%$, personnel risk $-15.0 \%$, operational risk $-11.0 \%$, security risk $-9.0 \%$, legal risk $-8.0 \%$ and other risks $-1.0 \%$.

Based on the processed research results in the V4 countries, we can state that the identified key risks for enterprises similarly developed. The enterprises in these countries assessed the market risks, especially those connected with placing goods and services in the domestic and foreign markets, as the biggest threat. Financial, personnel, and economic risks were identified as the second, third, and fourth most serious risks in the V4 countries, respectively. The sequence of these risks was only slightly different in individual countries. 


\subsection{Assessment of the market and economic risks by OMEs from the perspective of their LE in the V4 countries - the 2017-2018 survey}

It was necessary to use descriptive statistics to better analyse the assessed data and to verify the established hypotheses (Table 3).

Tab.3 - BDCHSs of individual risks in three groups of enterprises according to LE. Source: own research

\begin{tabular}{|l|l|l|l|l|}
\hline \multirow{2}{*}{ Risks } & \multirow{4}{*}{ BDCHS } & \multicolumn{3}{|l|}{ Interval of entrepreneurship } \\
\cline { 3 - 5 } & $\begin{array}{l}\text { Less than five } \\
\text { years }\end{array}$ & $\begin{array}{l}\text { From five to ten } \\
\text { years }\end{array}$ & $\begin{array}{l}\text { More than ten } \\
\text { years }\end{array}$ \\
\hline \multirow{5}{*}{ MRs/ERs } & $\mathrm{N}$ & 388 & 480 & 913 \\
\cline { 2 - 5 } & $\mathrm{M}$ & $0.28 / 0.18$ & $0.31 / 0.10$ & $0.34 / 0.19$ \\
\cline { 2 - 5 } & median & $0.30 / 0.20$ & $0.30 / 0.20$ & $0.30 / 0.20$ \\
\cline { 2 - 5 } & $\Sigma$ & $0.23 / 0.20$ & $0.23 / 0.21$ & $0.25 / 0.21$ \\
\cline { 2 - 5 } & skewness & $0.56 / 1.11$ & $0.36 / 0.96$ & $0.42 / 1.06$ \\
\cline { 2 - 5 } & kurtosis & $-0.09 / 0.87$ & $-0.29 / 0.56$ & $-0.34 / 0.79$ \\
\hline
\end{tabular}

Note: MR - Market risks; ER - Economic risks; $\mathrm{N}$ - number of statistic units, $\mu$ - the average intensity of risk to the enterprise. Source: own data collection.

The results of the research show that the most important risks are market risks (MRs) and economic risks (ERs), which are most often perceived by enterprises in the V4 countries based on LE. Based on the Grubbs test of extreme values, extremes were not identified. Bartlett's test $(\mathrm{MR}: \mathrm{p}$ value $=0.130 ; \mathrm{ER}: \mathrm{p}$ value $=0.069)$ and Levin's test of sphericity $(\mathrm{MR}: \mathrm{p}$ value $=0.103$; ER: $\mathrm{p}$ value $=0.480)$ confirmed the assumption of sphericity. Based on the goodness of fit test, for enterprises running a business for less than 5 years (MR: $\mathrm{p}$ value $=0.131$; ER: $\mathrm{p}$ value $=$ 0.086 ), from 5 to 10 years (MR: $\mathrm{p}$ value $=0.119$; ER: $\mathrm{p}$ value $=0.0 .073)$, and for more than 10 years $(\mathrm{MR}: \mathrm{p}$ value $=0.090 ; \mathrm{ER}: \mathrm{p}$ value $=0.097)$, the assumption of normality was considered fulfilled.

Tab. 4 - Analysis of the intensity variance of the enterprise market and economic risks in the V4 countries. Source: own research

\begin{tabular}{|l|l|l|l|l|}
\hline \multirow{2}{*}{ LE } & \multicolumn{2}{|l|}{ Market risks } & \multicolumn{2}{l|}{ Economic risks } \\
\cline { 2 - 5 } & N & $\begin{array}{l}\text { The average per } \\
\text { group }\end{array}$ & N & $\begin{array}{l}\text { The average per } \\
\text { group }\end{array}$ \\
\hline$>5$ years & 388 & 68.23 & 388 & 52.96 \\
\hline From 5 to 10 years & 480 & 45.28 & 480 & 40.85 \\
\hline From 10 to 20 years & 913 & 55.99 & 913 & 53.02 \\
\hline F-test (P-value) & 0.039 & & 0.001 & \\
\hline
\end{tabular}

Note: $\mathrm{N}$ - Number of enterprises

Based on the one-way ANOVA, the p values for the intensity of the market and economic risks perceived by OMEs in the V4 countries were less than 0.05 (MR: $\mathrm{p}$ value $=0.039 ; \mathrm{ER}=\mathrm{p}$ value 
$=0.001$; Table 5). Therefore, we can state that there is a statistically significant difference in the perception of the market and economic risks by OMEs in the V4 countries based on LE. We can reject the established hypotheses H1A_V4 and H1B_V4, i.e., OMEs in the V4 countries perceive different market risks and economic risks during the length of running a business. They perceive the market and economic risks mainly at the beginning of their business, which changes over time.

\subsection{Comparison of the processed results from the studies in 2017-2018 and 2019- 2020}

Based on the established statistical Hypothesis H1 and the results of the selected statistical tests, we can compare the results obtained to best describe the perceived market and economic risks not only in SR but also in the V4 countries. The comparison provided assesses the significant determinants of the market and economic risks by OMEs based on LE in SR (in 2019-2020) and the V4 countries (2017-2018). The summarized results are presented in Table 5. We can state that there are only small differences in the results of the selected descriptive statistics. The selected indicators did not show significant differences. Therefore, it can be concluded that the results of similar research will be the same in the V4 countries.

Tab. 5 - Summary results of the BDCHSs of the individual risks in the four groups of enterprises according to LE in the V4 countries and SR. Source: own research

\begin{tabular}{|c|c|c|c|c|c|c|c|c|c|c|c|c|c|}
\hline \multirow{2}{*}{$\begin{array}{l}\text { Type of } \\
\text { risks }\end{array}$} & \multirow{2}{*}{ LE } & \multicolumn{2}{|l|}{$\mathrm{N}$} & \multicolumn{2}{|l|}{ M } & \multicolumn{2}{|c|}{ median } & \multicolumn{2}{|l|}{$\Sigma$} & \multicolumn{2}{|c|}{ skewness } & \multicolumn{2}{|c|}{ kurtosis } \\
\hline & & SR & V4 & SR & $\mathrm{V} 4$ & SR & $\mathrm{V} 4$ & SR & $\mathrm{V} 4$ & SR & $\mathrm{V} 4$ & SR & $\mathrm{V} 4$ \\
\hline \multirow{4}{*}{ MRs } & $>5$ years & 60 & 388 & 0.28 & 0.28 & 0.30 & 0.30 & 0.26 & 0.23 & 0.90 & 0.56 & 0.79 & -0.09 \\
\hline & $5-10$ years & 110 & 480 & 0.27 & 0.31 & 0.30 & 0.30 & 0.23 & 0.23 & 0.75 & 0.36 & 0.8 & -0.29 \\
\hline & $\begin{array}{l}10-20 \\
\text { years }\end{array}$ & 122 & \multirow[t]{2}{*}{913} & 0.28 & \multirow[t]{2}{*}{0.34} & 0.30 & \multirow[t]{2}{*}{0.3} & 0.23 & \multirow[t]{2}{*}{0.26} & 0.19 & \multirow[t]{2}{*}{0.42} & -0.76 & \multirow[t]{2}{*}{-0.34} \\
\hline & $<20$ years & 130 & & 0.29 & & 0.30 & & 0.23 & & 0.37 & & -0.15 & \\
\hline \multirow{4}{*}{ ERs } & $>5$ years & 60 & 388 & 0.20 & 0.19 & 0.2 & 0.2 & 0.16 & 0.20 & 0.18 & 1.11 & -0.72 & 0.87 \\
\hline & $5-10$ years & 110 & 480 & 0.24 & 0.192 & 0.3 & 0.2 & 0.20 & 0.21 & 0.68 & 0.96 & 0.76 & 0.56 \\
\hline & $\begin{array}{l}10-20 \\
\text { years }\end{array}$ & 122 & \multirow[t]{2}{*}{913} & 0.17 & \multirow[t]{2}{*}{0.20} & 0.2 & \multirow[t]{2}{*}{0.2} & 0.18 & \multirow[t]{2}{*}{0.22} & 0.47 & \multirow[t]{2}{*}{1.06} & -1.17 & \multirow[t]{2}{*}{0.79} \\
\hline & $<20$ years & 1130 & & 0.16 & & 0.1 & & 0.18 & & 1.23 & & 1.93 & \\
\hline
\end{tabular}

Note: $\mathrm{N}$ - number of statistic units.

It was necessary to conduct the best tests to assess the data normality. Tests were selected by coverage of the dataset. The D'Agostino test $(\mathrm{N}<100)$ and goodness of fit test $(\mathrm{N}>100)$ were used. Two tests, the Levin and Bartlett tests, were applied to assess the sphericity. It was necessary to determine if the dataset contains some outliers. The Grubbs test was used to identify the outliers. The test results (from the datasets in 2017-2018 and 2019-2020) were very similar (Table $6)$, and the changes were negligible when comparing the test results. 
Tab. 6 - Comparison of summary results of selected tests in the V4 countries and SR. Source: own research

\begin{tabular}{|c|c|c|c|c|c|c|c|c|c|c|c|c|}
\hline & \multirow{2}{*}{\multicolumn{2}{|c|}{$\begin{array}{l}\text { Outliers } \\
\text { test }\end{array}$}} & \multicolumn{4}{|c|}{ Test of homoscedasticity } & \multicolumn{4}{|c|}{ Test of normality } & \multirow{2}{*}{\multicolumn{2}{|c|}{$\mathrm{p}$-value }} \\
\hline & & & \multicolumn{2}{|c|}{$\begin{array}{l}\text { Bartletts test } \\
\text { (P-values) }\end{array}$} & \multicolumn{2}{|c|}{$\begin{array}{l}\text { Levinov test } \\
\text { (P-values) }\end{array}$} & \multicolumn{2}{|c|}{ D'Agostinov } & \multicolumn{2}{|c|}{ Test of good fit } & & \\
\hline \multirow{2}{*}{ LE } & \multicolumn{12}{|c|}{ Market risks } \\
\hline & SR & V4 & SR & V4 & SR & V4 & SR & V4 & SR & V4 & SR & V4 \\
\hline$>5$ years & NO & NO & \multirow{4}{*}{0.11} & \multirow{4}{*}{0.10} & \multirow{4}{*}{0.32} & \multirow{4}{*}{0.26} & 0.0501 & - & - & 0.1311 & \multirow{4}{*}{0.040} & \multirow{4}{*}{0.0390} \\
\hline $5-10$ years & NO & $\mathrm{NO}$ & & & & & - & - & 0.069 & 0.1187 & & \\
\hline $10-20$ years & NO & $\mathrm{NO}$ & & & & & - & - & 0.131 & \multirow{2}{*}{0.0901} & & \\
\hline$<20$ years & NO & NO & & & & & - & - & 0.089 & & & \\
\hline \multirow{2}{*}{ LE } & \multicolumn{12}{|c|}{ Economic risks } \\
\hline & SR & V4 & SR & V4 & SR & V4 & SR & V4 & SR & V4 & SR & V4 \\
\hline$>5$ years & NO & NO & \multirow{4}{*}{0.069} & \multirow{4}{*}{0.069} & \multirow{4}{*}{0.306} & \multirow{4}{*}{0.480} & 0.100 & - & - & 0.0857 & \multirow{4}{*}{0.012} & \multirow{4}{*}{0.0013} \\
\hline $5-10$ years & NO & NO & & & & & - & - & 0.079 & 0.0733 & & \\
\hline $10-20$ years & NO & \multirow{2}{*}{ NO } & & & & & - & - & 0.099 & \multirow{2}{*}{0.0966} & & \\
\hline$<20$ years & NO & & & & & & - & & 0.063 & & & \\
\hline
\end{tabular}

Based on the results described in Table 5 and Table 6, we can conclude that differences between the perception of the market and economic risks by owners and managers in SR and the V4 countries based on LE are marginal. We failed to reject Hypothesis H2.

\section{DISCUSSION}

The global entrepreneurial environment is a major challenge for enterprises seeking to expand their entrepreneurial activities; however, it is a great risk if their business plans are not successful. The aggressive competition and permanent changes in the costs of materials, tax and insurance burdens, and growth of the processes of all types of energy are sources of many problems that can lead not only to market share losses but also to remarkable financial losses (Hudáková \& Masar, 2018). In the current strong competitive environment, it is important that enterprises assess the market and economic risks. This is confirmed by the results of our empirical research in the V4 countries.

Market risks have been identified as the most serious risks that owners and managers perceive based on processed data from the 2019-2020 results. Similar results were obtained for 2017-2018. Furthermore, we can conclude that there is a statistically significant difference in the perception of market risks by OMEs in SR in terms of LE (less than 5 years, 5-10 years, 10-20 years, and more than 20 years). These OMEs perceive other risks at the beginning of their businesses, and these risks gradually change with their time in the market. According to Belas et al. (2018), market risks are specific, and this may also be due to the impact of sources of risk that are changing in the marketplace as a business operates. The OMEs in SR identified the market risks in 2019 from the perspective of the most perceived sources: customer losses, strong business competition, market stagnation, and unreliable suppliers. The results are almost identical to each other compared to the results achieved by the V4 countries. Regarding the V4 countries, in 2017- 
2018, there was the risk of strong competition in the industry, the risk of unreliable suppliers, and the risk of market stagnation. Other authors who conducted similar investigations confirm these results. According to Popp et al. (2018), the abilities of enterprises to utilise competitive advantages and to overcome market risks are connected with the time of running a business in a market. According to Oláh et al. (2019), the longer enterprises operate in a market, the better the background they possess and the more able they are to fight against the negative changes in the entrepreneurial environment. However, a qualified workforce that is able to utilise market opportunities in the current turbulent entrepreneurial environment and, at the same time, to implement ERM procedures requires the ability to respond to unfavourable changes in the environment (Pietrasieński \& Ślusarczyk, 2015).

Economic risks have been identified as the second most serious risks that owners and managers perceive based on the processed data from the 2019-2020 results. The same severity was also found by assessing risks in the V4 countries in 2017-2018. There was a statistically significant difference in the perception of economic risks by owners and managers in SR in terms of LE (less than 5 years, 5-10 years, 10-20 years, and more than 20 years). They perceive other risks at the beginning of their businesses, which gradually changes with their time in the market. Economic risks are often the most difficult risks to foresee (Belas et al., 2018). This may also be due to the impact of sources of risk that change during the operations of the enterprises in a market. The sources of the economic risks perceived by OMEs in SR in 2019-2020 are also interesting. In this period, the economic risks were the growth of employee wages, increased tax and insurance burdens, and insufficient availability of financial resources. The results are almost identical to each other compared to the results achieved by the V4 countries. Regarding the V4 countries, in 2017-2018, the risk of increased tax and insurance burdens, the risk of increased interest rates, and the risk of the growth of the processes of all types of energy were included. Other authors who conducted similar investigations (Kozubíková et al., 2020; Oláh et al., 2019) confirm these results. According to Popp et al. (2018) and Roszko-Wójtowicz \& Grzelak (2020), increased total costs in terms of macroeconomic indicators is one of the economic risk factors that businesses need to identify and manage. When a market is competitive and these costs increase, consumers still expect to pay consistent prices, resulting in possible profit losses. Businesses need to proactively identify and monitor all these conditions to support a robust economic risk management strategy (Pietrasieński \& Ślusarczyk, 2015).

The processed results show that the V4 countries of Eastern Europe are most concerned about the market, economic, and financial risks. From the point of view of European countries, the results differ slightly. A study by the Cambridge Centre for Risk Studies Institute of Risk Management defines the top enterprise risks as follows: financial, operational performance, regulatory standards and reporting, reputation, enterprise security including cybersecurity, business continuity, macroeconomic factors, health and safety, geopolitical risk, human capital, market share, etc. (Brachert et al., 2017). According to a worldwide study, the Allianz Risk Barometer 2020 highlights that cyber risk and climate change are two significant challenges enterprises need to watch closely in the new decade. The most important business risks for 2020 are cyber incidents, business interruptions, legislative and regulatory changes, natural catastrophes, and market developments (Kücher et al., 2020). These results were confirmed by another study of The 
Global Risks Report 2020 (World Economic Forum, 2020). The key global risks for businesses are environmental, geopolitical, societal, technological, and economic risks. The results of the study declare that the risks currently faced by enterprises have reached a new record, which was mainly due to the outbreak of the new coronavirus. The negative situation shows how unexpected events can suddenly worsen the business environment worldwide (Thorgren \& Williams, 2020; Lu et al., 2020). The global economy is facing an increased risk of stagnation, climate change is striking harder and more rapidly, and fragmented cyberspace threatens the full potential of nextgeneration technologies (Agarwal \& Ansell, 2016). The survey results emphasize that business decision-makers must have preventive measures and crisis plans in place to respond to abruptly disrupted supply chains and business continuity (Bendickson et al., 2018).

\section{CONCLUSION}

The aim of the paper was to define and quantify the most significant business risks and show the differences in these risks according to the length of a business's existence.

The research results highlight the importance of assessing the key business risks (market and economic risks) and their resources in the enterprises in the V4 countries. The research results in SR in 2019-2020 and the V4 countries in 2017-2018 showed that OMEs perceive the market and economic risks as the risks with the most negative impacts on enterprise success. The processed results for all the countries are related. OMEs perceive differences in the market and economic risks in terms of LE not only in SR but also in the V4 countries. The main benefits of the paper are the following: i. the paper studies the key risks perceived by OMEs in SR and V4 countries; ii. the paper assesses the important sources connected with the perception of the level of market and economic risks by owners and managers regarding LE in the V4 countries; and iii. the paper improves the awareness of ERM to support the business success, regional development of the regions, and, last but not least, cooperation of the V4 countries.

The research limitation of this article was finding OMEs having participated in the case study in Central European countries (V4). It is necessary to stress that the research has focused on entrepreneurs in individual years. The individual results can be perceived and related to a given data collection period. This article analyses and assesses two statistical datasets: $i$. the first dataset is limited to 2019-2020, and the individual data are related to the territory of SR only; and ii. the second dataset is limited to 2017-2018, and the individual data refer to V4 countries. As for the research sample, a partial limitation existed in 2019-2020. A relatively small number of respondents participated in the survey, which was caused mainly by the lack of perceived added value of entrepreneurship risk management by entrepreneurs and managers in SR. This, however, did not cause significant differences in the analysed sample. It can be assumed that a larger sample of respondents would not significantly affect the results presented in the article. The research results, as well as tests, can be seen as very useful for further surveys.

It is important that managers are convinced that effective ERM provides fewer negative surprises, greater financial stability, and improved competitiveness. Improving the level of risk management, therefore, requires enterprises in the V4 countries to acquire theoretical knowledge of the risk management process, methods, and tools. The actual results of the research will be 
publicly provided to the managers of enterprises in the V4 countries through a website. Business managers who encounter risks every day will be better informed about the potential threats. It could emphasise reducing risks, overall prevention in their enterprise, and increasing their enterprise's competitiveness. In future studies, the team of authors will focus on the creation and promotion of the concept of risk culture so that managers take positive attitudes towards risks that result from global trends in the issues addressed. Further research will focus on comparing the results of the assessed business risks before and during the COVID-19 pandemic. The authors want to take gradual steps towards enforcement of ERM in the V4 countries for the associated enterprises to approach the global trends. The achieved results are valuable for entrepreneurs, enterprise managers and institutions that provide comprehensive entrepreneurship support in V4 countries. The overall results are significant at the regional, national, and international levels of the V4 countries and can strengthen the competitiveness of entrepreneurs within the EU common market. The results contribute to enhancing the coordination and cooperation between individual V4 countries in order to increase economic development and enterprise resilience to global impacts.

Acknowledgements: Publication of this paper was supported by the Scientific Grant Agency the project VEGA No. 1/0243/20 - Integrated risk management system in the conditions of contemporary changes in enterprise environment in Slovakia.

\section{References}

1. Achim, M. V., Safta, I. V., Văidean, V. L., Muresan, G. M., \& Borlea, N. S. (2021). The impact of covid-19 on financial management: evidence from Romania. Economic Research. Ahead of print, 1-26. https://dx.doi.org/10.1080/1331677X.2021.1922090

2. Adapa, S., \& Fisher, J. (2020). Owner-managers' perceptions of corporate social responsibility practices within small and medium-sized accounting firms - an Australian study. International Journal of Enterprise Network Management, 11 (2), 164-188.

http://dx.doi.org/10.1504/IJENM.2020.106311

3. Adkins, C. L., Samaras, S. A., Gilfillan, S. W., \& Mcwee, W. E. (2013). The relationship between owner characteristics, company size, and the work-family culture and policies of women-owned businesses. Journal of Small Business Management, 51 (2), 196-214. http://dx.doi.org/10.1111/jsbm.12014

4. Agarwal, R., \& Ansell, J. (2016). Strategic change in enterprise risk management. Strategic Change, 25 (4), 427-439. http://dx.doi.org/10.1002/jsc.2072

5. Avilova, T. V., Voytolovskiy, N. V., Dikareva, V. A., \& Chernysheva, A. M. (2017). The efficiency of applying risks management systems at industrial enterprises under market conditions. Journal of Applied Economic Sciences, 12 (3), 766-771.

6. Ayyagari, M., Beck, T., \& Demirguc-Kunt, A. (2007). Small and medium enterprises across the globe. Small Business Economics, 29 (4), 415-434.

http://dx.doi.org/10.1007/s11187-006-9002-5

7. Beasley, M. S., \& Frigo, M. L. (2011). ERM and its role in strategic planning and strategy execution. Enterprise risk management. New Jersey: John Wiley \& Sons. 
8. Belas, J., Amoah, J., Petráková, Z., Kliuchnikava, Y., \& Bilan, Y. (2020). Selected Factors of SMEs Management in the Service Sector. Journal of Tourism and Services, 21 (11), 129-146. http://dx.doi.org/10.29036/jots.v11i21.215

9. Belas, J., Gavurova, B., \& Toth, P. (2018). Impact of selected characteristics of SMEs on the capital structure. Journal of Business Economics and Management, 19 (4), 592-608. http://dx.doi.org/10.3846/jbem.2018.6583

10. Bendickson, J., Gur, F. A., \& Taylor, E. C. (2018). Reducing environmental uncertainty: How high-performance work systems moderate the resource dependence-firm performance relationship. Canadian Journal of Administrative Sciences, 35 (2), 252-264. http://dx.doi.org/10.1002/cjas.1412

11. Bogodistov, Y., \& Wohlgemuth, V. (2017). Enterprise risk management: A capability-based perspective. Journal of Risk Finance, 18 (3), 234-251.

http://dx.doi.org/10.1108/JRF-10-2016-0131

12. Brachert, M., Hyll, W., \& Titze, M. (2017). On the simultaneity bias in the relationship between risk attitudes, entry into entrepreneurship and entrepreneurial survival. Applied Economics Letters, 24 (7), 477-480. http://dx.doi.org/10.1080/13504851.2016.1203056

13. Brunner-Kirchmair, T. M., \& Wiener, M. (2019). Knowledge is power - conceptualizing collaborative financial risk assessment. Journal of Risk. Finance, 20 (3), 226-248. http://dx.doi.org/10.1108/JRF-05-2018-0083

14. Chavarín, R. (2020). Risk governance, banks affiliated to business groups, and foreign ownership. Risk Management, 22 (1), 1-37, http://dx.doi.org/10.1057/s41283-019-00049-9

15. De Oliveira, U. R., Marins, F. A. S., Rocha, H. M., \& Salomon, V. A. P. (2017). The ISO 31000 standard in supply chain risk management. Journal of Cleaner Production, 151, 616-633. https://doi.org/10.1016/j.jclepro.2017.03.054

16. Dean, H., Larsen, G., Ford, J., \& Akram, M. (2019). Female entrepreneurship and the metanarrative of economic growth: A critical review of underlying assumptions. International Journal of Management Reviews, 21 (1), 24-49. http://dx.doi.org/10.1111/ijmr.12173

17. Demirbas, D., Hussain, J. G., \& Matlay, H. (2011). Owner-managers' perceptions of barriers to innovation: Empirical evidence from Turkish SMEs. Journal of Small Business and Enterprise Development, 18 (4), 764-780. http://dx.doi.org/10.1108/14626001111179794

18. Dvorský, J., Čepel, M., Simionescu, M., \& Ďurana, P. (2021). The influence of competitiveness on start-up in SMEs segment. E a M: Ekonomie a Management, 24 (1), 102-117. http://dx.doi.org/10.15240/TUL/001/2021-1-007

19. Dvorský, J., Petráková, Z., \& Polách, J. (2019). Assessing the Market, Financial, and Economic Risk Sources by Czech and Slovak SMEs. International Journal of Entrepreneurial Knowledge, 7 (2), 30-40. http://dx.doi.org/10.12345-0008

20. Egbunike, C. F., \& Okerekeoti, C. U. (2018). Macroeconomic factors, firm characteristics and financial performance. Asian Journal of Accounting Research, 3 (2), 142-168.

21. Fraser, J. R. S., \& Simkins, B. J. (2016). The challenges of and solutions for implementing enterprise risk management. Business Horizons, 59 (6), 689-698. http://dx.doi.org/10.1016/j.bushor.2016.06.007 
22. Gavurova, B., Packova, M., Misankova, M., \& Smrcka, L. (2017). Predictive potential and risks of selected bankruptcy prediction models in the Slovak business environment. Journal of Business Economics and Management, 18 (6), 1156-1173. http://dx.doi.org/10.3846/16111699.2017. 1400461

23. Gilmore, A., Carson, D., \& O’Donnell, A. (2004). Small-business owner-managers and their attitude to risk. Marketing Intelligence \& Planning, 22 (3), 349-360.

http://dx.doi.org/10.1108/02634500410536920

24. Green, P. E. J. (2016). Enterprise risk management: a common framework for the entire organization. Amsterdam: Elsevier, Butterworth-Heinemann.

25. Hernández-Madrigal, M., Aibar-Guzmán, C., Aibar-Guzmán, B., \& Ramírez-Flores, É. (2020). Are external pressures always behind ERM implementation? Evidence from spanish listed firms. International Journal of Disclosure and Governance, 17 (2), 86-100.

http://dx.doi.org/10.1057/s41310-020-00076-z

26. Hnilica, J., Uhlaner, L. M., Machek, O., Kubíček, A., Lukeš, M., Jurek, M., \& Štamfestová, P. (2019). The role of responsible ownership and family in privately held firms with multiple owners: Preliminary findings from the Czech Republic. Central European Business Review, 8 (5), 1-17. http://dx.doi.org/10.18267/j.cebr.231

27. Holla, K. Zanicka, Ristvej, J., \& Simak, L. (2010). A systematic method of risk assessment in industrial processes, Risk Analysis 2010 - 7th International Conference on Computer Simulation in Risk Analysis and Hazard Mitigation, 43, 115-126, http://dx.doi.org/10.2495/RISK100111

28. Hudáková, M., \& Masár, M. (2018). The assessment of key business risks for SMEs in Slovakia and their comparison with other EU countries. Entrepreneurial Business and Economics Review, 6 (4), 145-160. http://dx.doi.org/10.15678/EBER.2018.060408

29. Hvolkova, L., Klement, L., Klementova, V., \& Kovalova, M. (2019). Barriers Hindering Innovations in Small and Medium-Sized Enterprises. Journal of Competitiveness 11 (2), 51-67. http://dx.doi.org/10.7441/joc.2019.02.04

30. Khan, K. A., Çera, G., \& Nétek, V. (2019). Perception of the Selected Business Environment Aspects by Service Firms. Journal of Tourism and Services, 10 (19), 111-127. https://doi.org/10.29036/jots.v10i19.115

31. Kiseleva, I. A., Karmanov, M. V., Korotkov, A. V., Kuznetsov, V. I., \& Gasparian, M. S. (2018). Risk management in business: Concept, types, evaluation criteria. Espacios, 39 (27), $1-18$.

32. Klinke, A. (2021). Public understanding of risk and risk governance. Journal of Risk Research, 24 (1), 2-13. https://doi.org/10.1080/13669877.2020.1750464

33. Ključnikov, A., Civelek, M., Fialova, V., \& Folvarčná, A. (2021). Organizational, local, and global innovativeness of family-owned SMEs depending on firm-individual level characteristics: evidence from the Czech Republic. Equilibrium. Quarterly Journal of Economics and Economic Policy, 16 (1), 169-184. https://doi.org/10.24136/eq.2021.006

34. Kozubíková, L., Dvorský, J., \& Ključnikov, A. (2020). Social factors’ impact on the quality of the business environment in the SME segment. Scientific Papers of the University of Pardubice, Series D: Faculty of Economics and Administration, 28 (1), 91-102. 
35. Kücher, A., Mayr, S., Mitter, C., Duller, C., \& Feldbauer-Durstmüller, B. (2020). Firm age dynamics and causes of corporate bankruptcy: Age-dependent explanations for business failure. Review of Managerial Science, 14 (3), 633-661. https://doi.org/10.1007/s11846-018-0303-2

36. Kulathunga, K. M. M. C. B., Ye, J., Sharma, S., \& Weerathunga, P. R. (2020). How does technological and financial literacy influence SME performance: Mediating role of ERM practices. Information (Switzerland), 11 (6). https://doi.org/10.3390/INFO11060297

37. Lazányi, K., Virglerová, Z., Dvorský, J., \& Dapkus, R. (2017). An analysis of factors related to "taking risks", according to selected socio-demographic factors. Acta Polytechnica Hungarica, 14 (7), 35-50. https://dx.doi.org/10.12700/APH.14.7.2017.7.3

38. Lechner, P., \& Gatzert, N. (2018). Determinants and value of enterprise risk management: Empirical evidence from Germany. European Journal of Finance, 24 (10), 867-887. https://doi.org/10.1080/1351847X.2017.1347100

39. Lončarski, I., \& Marinč, M. (2020). The political economy of relationship banking. Research in International Business and Finance, 51, 101078. https://doi.org/10.1016/j.ribaf.2019.101078

40. Lu, Y., Wu, J., Peng, J., \& Lu, L. (2020). The perceived impact of the covid-19 epidemic: Evidence from a sample of 4807 SMEs in Sichuan province, China. Environmental Hazards, 19 (4), 323-340. https://doi.org/10.1080/17477891.2020.1763902

41. Mura, L., \& Kajzar, P. (2019). Small Businesses in Cultural Tourism in a Central European Country. Journal of Tourism and Services, 10 (19), 40-54. https://doi.org/10.29036/jots.v10i19.110

42. Oláh, J., Kovács, S., Virglerova, Z., Lakner, Z., Kovacova, M., \& Popp, J. (2019). Analysis and comparison of economic and financial risk sources in SMEs of the Visegrad group and Serbia. Sustainability (Switzerland), 11 (7). https://doi.org/10.3390/su11071853

43. Pietrasieński, P., \& Ślusarczyk, B. (2015). Internationalization of small and medium enterprises - empirical research review on barriers to entry into foreign markets. Polish Journal of Management Studies, 11 (1), 113-123.

44. Popp, J., Oláh, J., Machova, V., \& Jachowicz, A. (2018). Private equity market of the Visegrad group. Ekonomicko-manazerske spectrum, 12 (1), 1-15. https://doi.org/10.26552/ems.2018.1.1-15

45. Racicot, F. E., \& Théoret, R. (2018). Multi-moment risk, hedging strategies, \& the business cycle. International Review of Economics and Finance, 58, 637-675. https://doi.org/10.1016/j.iref.2018.07.006

46. Reçica, F., Hashi, I., Jackson, I., \& Krasniqi, B. A. (2019). Innovation and the export performance of firms in transition economies: The relevance of the business environment and the stage of transition. International Journal of Entrepreneurship and Small Business, 38 (4), 476-506. https://doi.org/10.1504/IJESB.2019.104141

47. Roszko-Wójtowicz, E., \& Grzelak, M. M. (2020). Macroeconomic stability and the level of competitiveness in EU member states: A comparative dynamic approach. Oeconomia Copernicana, 11 (4), 657-688. https://doi.org/10.24136/OC.2020.027

48. Schmidt, C. (2020). Why risk management frameworks fail to prevent wrongdoing. Learning Organization, 27 (2), 133-145. https://doi.org/10.1108/TLO-10-2019-0150

49. Smith, M. (2020). Effective Leadership in Online Small Businesses: an Exploratory Case Study. International Journal of Entrepreneurial Knowledge, 8 (2), 27-41. https://doi.org/10.37335/ijek.v8i2.117 
50. Thorgren, S., \& Williams, T. A. (2020). Staying alive during an unfolding crisis: How SMEs ward off impending disaster. Journal of Business Venturing Insights, 14, e00187.

https://doi.org/10.1016/j.jbvi.2020.e00187

51. Varadarajan, R. (2020). Customer information resources advantage, marketing strategy and business performance: A market resources based view. Industrial Marketing Management, 89, 89-97. https://doi.org/10.1016/j.indmarman.2020.03.003

52. Virglerova, Z., Conte, F., Amoah, J., \& Massaro, M. R. (2020). The Perception of Legal Risk and Its Impact on the Business of SMEs. International Journal of Entrepreneurial Knowledge, 8 (2), 1-13. https://doi.org/10.37335/ijek.v8i2.115

53. World Economic Forum (2020). The Global Risks Report 2020, World Economic Forum, available at: http://www3.weforum.org/docs/WEF_Global_Risk_Report_2020.pdf

54. Wu, D., Olson, D. L., \& Dolgui, A. (2015). Decision making in enterprise risk management: A review and introduction to a special issue. Omega (United Kingdom), 57 (A), 1-4. https://doi.org/10.1016/j.omega.2015.04.011

\section{Contact information}

Assoc. prof. Ing. Maria Hudakova, Ph.D.

University of Žilina, Faculty of Security Engineering,

Department of Crisis Management

Slovakia

E-mail:maria.hudakova@fbi.uniza.sk

ORCID: 0000-0002-0756-0962

Dr. Ing. Marie Gabrysova, prof. GWSH

Katowice Business University, Faculty of Management

Poland

E-mail:marie.gabrysova@gwsh.pl

ORCID: 0000-0002-7273-4762
Assoc. prof. Ing. Katarina Buganova, Ph.D.

University of Žilina, Faculty of Security Engineering,

Department of Crisis Management

Slovakia

E-mail:katarina.buganova@fbi.uniza.sk

ORCID: 0000-0002-0596-5229

Assoc. prof. RNDr. Vladimir Krajcik, Ph.D.

University College of Business in Prague

Crech Republic

E-mail:krajcik@vso-praha.eu

ORCID: 0000-0003-2234-3939

Assoc. prof. Ing. Zora Petrakova, Ph.D.

Slovak. University of Technology in Bratislava,

Faculty of Civil Engineering, Institute of Civil

Engineering

Slovakia

E-mail: zora.petrakova@stuba.sk

ORCID:0000-0002-1398-9415 